in their value for bacon. Useful information is given regarding sheep breeding in Britain, Canada, Australia, New Zealand and South Africa, and the varying problems each country has to face. We learn that the world's record for butter-fat production -1,614 lb. in a year-is held by an Australian Shorthorn, that Romney Marsh sheep are successful in New Zealand, and that camel breeding is developed by Government in the Sudan. Zebu cattle and buffaloes have been introduced from India into the West Indies, Tanganyika and British Guiana. Cattle suitable for the tropics can probably be produced by crosses between zebu and certain European breeds. Such crosses between zebu cows and Friesian bulls have produced a satisfactory breed in Trinidad, but Krishna Valley zebu in Tanganyika crossed with Devons or Aberdeen Angus give intractable animals unsuitable for domestic uses.

\section{National Institute of Agricultural Botany}

THE fourteenth report of the National Institute of Agricultural Botany records considerable progress in the selection and multiplication of improved crops. Exhaustive tests of yield of many farm and garden plants have been made in different districts, and authoritative comparisons of varieties are now avail able. Considerable research is being devoted to problems of seed-testing, and a large number of routine tests have been made for other investigators. The classical potato trials at Ormskirk, Lancs, seem to have suffered from severe climatic conditions, but the work on potato synonyms progresses satisfactorily, and should do much to protect the farmer and gardener from unfair exploitation. The head office of the Institute is in Huntingdon Road, Cambridge, and a very close co-operation is maintained with related organisations.

\section{Ichthyology in the United States}

THE twentieth anniversary number of Copeia (No. 4, December 1933. American Society of Ichthyologists and Herpetologists), which deals with fishes, reptiles and amphibians, is dedicated to its founder, John Treadwell Nicholls. In it are included many interesting and valuable papers, notable among them being "Deep-Sea Stomiatoid Fishes" by William Beebe, in which one new genus and eight new species are described from the Bermuda Oceanographic Expeditions of the Department of Tropical Research of the New York Zoological Society. These were all taken within the eight-mile circle, the centre of which is at lat. $32^{\circ} 12^{\prime} \mathrm{N}$., long. $64^{\circ} 36^{\prime} \mathrm{W}$., $9 \frac{1}{4}$ miles south-south-west of Nonsuch Island, Bermuda. The barbels of some of these fishes are very peculiar ; one of them, belonging to Ultimostomias mirabilis gen. et sp.nov., has a barbel measuring $417 \mathrm{~mm}$. in length (more than ten times the length of the fish itself). Other papers on fish are by Albert Eide Parr, George S. Myers, E. W. Gudger and C. M. Breder, Jr. A new snake from Panama is described by $E$. $R$. Dunn and there is an interesting article on the immunity of rattlesnakes to their venom by $\mathbf{A}$. A. Nichol, Volney Douglas and Lewellyn Peck. Other papers are on the nests and young of the Allegheny salamander, the ophidian generic names Ahaetulla and Dendrophis, secondary sexual characters of Bufo melanostictus, and Pseudemys troostii-elegans complex, a case of sexual dimorphism.

\section{Strength of Spirits}

As is well known, the Finance Act of 1915 provided that where by reason of the high temperature or strength of spirits the ordinary Sikes hydrometer was not applicable, the strength may be ascertained by means of the supplemental Sikes $A$ hydrometer, using tables identified as II and IV prepared by the late Sir Edward Thorpe when principal of the Government Laboratory. Under the Strength and Weight of Spirits Ascertainment Regulations, 1930, when the same conditions of high temperature or strength apply, the use of a further supplemental Sikes $B$ hydrometer is permitted. When this is used without the poise marked $A$ attached, Tables $\mathrm{V}$ and VI prepared by Sir Robert Robertson are applicable. Tables II, IV, V and VI have been issued under the authority of the Commissioners of H.M. Customs and Excise in one volume at 2s. 6d. (London: H.M. Stationery Office): the ordinary tables I and III are printed in a separate volume. The tables cover temperatures from $30^{\circ}$ to $100^{\circ} \mathrm{F}$.

\section{Institution of Petroleum Geologists}

THE summer meeting of the Institution of Petroleum Technologists will be held in London at the Royal Society of Arts on June 28-29. The programme consists of a series of papers, available in advance, on general topics which will be submitted for discussion. The subjects of the first day's discussions are the relation of oil and coal to the petroleum industry, measurement of oil in bulk, and the format of the Institution's Journal. The second day is being given to a series of reports on the progress of naphthology; the Refining and Chemical Section, under the chairmanship of Dr. F. H. Garmer, will occupy the morning session, while the Field Technology, Geology and General Sections, under the chairmanship of Mr. A. Beeby Thompson, will take up the afternoon session. During the course of the annual dinner on June 29, the Redwood Medal of the Institution will be presented to Dr. David White, of the U.S. Geological Survey, who is known for his studies in palæobotany. This medal is awarded biennially, and is given for contributions to our knowledge of petroleum technology.

\section{Rockefeller Medical Fellowships}

THE Medical Research Council announces that, on behalf of the Rockefeller Foundation of New York, it has made the following awards of travelling fellow. ships for the academic year 1934-35: Mr. I. Aird, demonstrator in anatomy, University of Edinburgh, and clinical tutor in surgery, Royal Infirmary, Edinburgh; Mr. I. A. Anderson, house physician, Royal Infirmary, Aberdeen; Prof. E. G. Oastler, professor of physiology, St. Mungo's College, Glasgow, 